\title{
Addressing the Challenges to Raising Productivity of Smallholder Farmers in Africa through Regularization of Rights to and Efficient use of Land Resources: Successful Model from Rwanda
}

\author{
Rashid Hassan* \\ Centre for Environmental Economics and Policy in Africa (CEEPA), University of Pretoria, South Africa
}

Submission: February 08, 2018; Published: March 21, 2018

"Corresponding author: Rashid Hassan, Centre for Environmental Economics and Policy in Africa (CEEPA), University of Pretoria, South Africa, Email: rashid.hassan@up.ac.za

\section{Introduction}

There seems to be consensus among national government and regional and international development agencies that an agriculture-led growth path is the best strategy for achieving economy-wide structural transformation in Africa [1-3]. Experiences of many Asian countries with the green revolution model provide a good example of successful pursuance of such goal. Growth in agricultural value added induced by significant productivity gains from wide-adoption of modern inputs and farming practices, such as improved seeds and animal breeds, fertilizers, mechanization and irrigation characterized the green revolution model of agricultural transformation.

African agriculture has enjoyed some growth in total value added and productivity levels over the past two decades. The observed productivity gains however, have been marginal and failed to catalyse broader structural economic transformation. The poor agricultural transformation performance in Africa is attributed to the low adoption of productivity enhancing modern inputs (e.g. non-land and non-labour inputs) [1-3]. It was accordingly concluded by many studies, that the observed growth in agricultural output in Africa came primarily from area expansion with little contributions from intensification (use of non-land inputs) ${ }^{1}$ [1-3]. Overcoming this intensification gap is therefore, the major challenge Africa faces on the way to achieving the desired agricultural transformation.

Two key obstacles to the uptake and investment in productivity enhancing solutions and technologies stand in the way of intensifying Africa's agriculture. Lack of or weak tenure security and rights to land is one constraint. The second is the typical small size of farms cultivated by the vast majority of farmers in the continent. Several policy measures and institutional reforms are needed to create the enabling environment for overcoming these obstacles and promoting the desired agricultural intensification. Reforming land tenure systems to ensure better security of rights to land for instance, is necessary for promoting farmers' investments in long-term improvements on their farm land [4-7]. Promoting wider and faster adoption of available intensification solutions also requires favourable structure of economic incentives. For instance, sufficient economic incentives are required to promote farmers' private investments in farm infrastructures for soil conservation, and water harvesting and storage; as well as investing in planting trees and acquisition of more efficient irrigation technologies, and productivity enhancing modern inputs (e.g. improved seed and fertilizers).

Rwanda provides a good example of successful policy and institutional reforms addressing these two obstacles [8]. As a result of the high population density (highest in Africa at 416 people $/ \mathrm{KM}^{2}$ ), land is seriously fragmented into an average size of holding of about 0.33 ha [9]. Scarcity of land is further aggravated by the fact that most of the 1.5 million hectares of Rwanda's arable land is on hillside terrain. Substantial encroachment of extensive cultivation on fragile steep hilly slopes has therefore been inevitable with severe soil erosion consequences. The Government of Rwanda (GoR) has accordingly embarked on ambitious agricultural development strategies and introduced

${ }^{1}$ The contribution of non-land inputs was estimated at $17 \%$ during the $2001-2008$ period, compared to a much larger share of $69 \%$ attributed to area expansion IFAD [1]. 
a number of agriculture sector and complimentary policy measures to address these structural challenges.

This paper documents the processes and outcomes of Rwanda's successful policy and institutional interventions to promote sustainable intensification of agricultural production. The Rwanda approach and experiences in dealing with the said policy and institutional constraints can be a guiding example to follow by other countries in their pursuit of structural transformation of agriculture and the national economy. We review in the following sections the design and impacts of two key policy and institutional reforms implemented in Rwanda: (1) the crop intensification program (CIP) and land use consolidation (LUC) for increasing agricultural productivity, (2) regularization of land tenure systems. Section 2 presents Rwanda's experience with implementing the CIP and its integral LUC component. The process and outcomes of Rwanda's regularization of land tenure systems to strengthen property rights in land are documented in Section 3. The paper concludes with a brief overview of complementary non-agriculture sector and macro policy reforms facilitating achieved structural shifts in the composition of domestic income and employment of key resources in Rwanda.

The Crop Intensification Program (CIP) and Land use Consolidation (LUC) for Increasing Agricultural Productivity

Agricultural production in Rwanda is predominantly practiced under smallholder subsistence systems where more than $70 \%$ of farmers cultivate less than 0.9 ha of land, which is slightly above the 0.7 ha considered to be the minimum farm size needed to sustain a family [10]. This clearly is a major productivity constraint. Another feature of Rwandan agriculture is the domination of food crops occupying more than $67.1 \%$ of all cultivable land and contributing $84 \%$ of agricultural GDP [11]. These structural features are behind giving priority to investments in realizing productivity gains from intensified food crops' production systems. The GoR has accordingly launched the crop intensification program (CIP) in 2007 to enhance productivity of key food crops for greater security and self-sufficiency in food in pursuit of the ultimate goals of the country's strategic Vision 2020 of eliminating poverty and attaining middle-income status $[12,13]$. The agricultural sector component of this national strategic vision and its constituent programs aim at transforming Rwandan agriculture from a traditional subsistence to an inclusive, modern, and marketoriented productive sector [14].

This favorable policy environment enabled channeling substantial shares of public funds to be invested in promoting use of productivity enhancing inputs and practices (e.g. improved seeds, fertilizers, irrigation, etc.) by smallholder farmers and establishment of soil conservation and other hillside terracing and marshland development infrastructures. An important component of the CIP is the land use consolidation (LUC) scheme launched in 2008 to address the nationwide problem of the small holding size constraint on productivity ${ }^{2}$. The LUC program promotes joining such small plots of several owners to be planted as one large unit to realize productivity gains from scale economies in acquisition and use of modern inputs and provision of extension advice and post-harvest processing and marketing services [15]. The LUC is voluntary, where farmers agree to join and plant their plots to the crops chosen by CIP in exchange of the support provided by the program of input supplies (improved seed, fertilizer), extension and some postharvest services [14].

A number of assessments of the impacts of these agricultural support programs have been conducted documenting huge success in achieving its productivity expansion, food security and poverty reduction goals [16-18]. The said studies report on historical performance records by 2012 in annual agricultural GDP growth (5.6\%), reduction in rural poverty by $49 \%$, growth in agricultural exports (44\%), GDP share investment in agriculture of $22.2 \%$, off-farm share in total employment $(26.6 \%)$, among others [9]. These impressive records have been attributed to major gains in crop productivity $(60 \%)$ and conservation achieved under the CIP where land under consolidated use (LUC) increased by more than 17 fold and protection against soil erosion reached $73 \%$ of the land with rates of use of inorganic fertilizers rising from $7 \%$ to $30 \%$ by 2012 [9].

Fear of losing land rights has been one major concern of farmers, slowing joining of the LUC program in its early stages. Although the long-term security of land tenure has been addressed to a large extend by the successful regularization of rights to land, many challenges remain regarding sustainability of the CIP. Key among those is sustainability of the uptake of modern inputs after cessation of CIP subsidies to prevent potential reversals [9,16-18].

\section{Regularization of Rights to Land}

Regardless of whether or not conflict over the control of land was the main contributing factor to the 1994 genocide in Rwanda, the civil war led to serious disruptions of existing settlement patterns and worsened disputes over ownership and access to land. Addressing the land rights of the millions of widowed women, orphans and displaced citizens left behind, and resolving land claims of returnees presented a huge challenge for the postwar administration [18-21]. Several legislations and policies have accordingly been introduced to establish definitive rights and security of land tenure in general (including formalization of customary rights), and to improve rights of disadvantaged

${ }^{2}$ Every rural family in Rwanda cultivates four very small land parcels on average, each of between 0.13 ha and 0.37 ha (Republic of Rwanda, 2004). 
groups (particularly women). The main legal and policy reforms instituted are: The New Inheritance Law of 1999, the National Land Policy of 2004, and the Organic Land Law (OLL) of 2005 $[10,15]$.

The said regulations provided an enabling legal framework for establishment of land administration institutions to support implementation of a nationwide Land Tenure Regularization (LTR) program and replace the dual customary and formal tenure regimes with a single statutory land tenure system. The LTR program launched in 2009 aimed at creating complete public registry of titles to all landholdings, with state ownership and long-term (up to 99 years depending on type of land use) usufruct rights to landholders that can be sold, leased, mortgaged or passed on to heirs. One key constraint stipulated however, is prohibition of further subdivision of land smaller than one ha and acquisition of approval for subdivision of land between one and five ha [14].

The main objective of LTR was to establish clear ownership rights and increase land tenure security to all citizens. In turn, security of land tenure is expected to increase land productivity by stimulating investments on land, increase access to credit, promote market transactions for efficient allocation of land to more productive uses, and reduce disputes over land and risk of expropriation (hence the costs of protecting property). The LTR program was tested and fine-tuned through extensive piloting prior to its countrywide implementation in 2009 and became a model for other countries to follow [22]. More than 10 million parcels were successfully registered and 8.4 million certificates of title were issued by 2013, constituting the vast majority of private land in Rwanda [23,24].

Some studies have evaluated the performance of Rwanda's LTR model and associated land reform programs. Ali et al. [25] found evidence of significant positive short-run impacts of the LTR program on investment in soil conservation and stronger land rights of legally married women. No significant changes in land market transactions were observed however, in the 2.5 years period post piloting the LTR program. This is nevertheless considered an indication of no serious immediate negative unintended consequences such as distress sales or landlessness [25]. A more recent comprehensive assessment of Rwanda's land reform experience suggests even stronger positive impacts in the medium-term of 6 years after implementation of the LTR [24]. The said study confirmed that title certificates had decisive influence on resolving land disputes, and considered by formal credit providers to be a sufficient security for acquiring a loan.

The Biraro et al. [24] study indicates that the cost/fees on registering transactions and land subdivision restrictions have negatively affected potential land market activities, suggesting the possibility of citizens engaging in selling and buying less than one hectare plots outside the formal system. It has also been suggested that the fixed transfer fees for registering land transactions be revised taking into consideration the size and value of market transferred properties and consider different bases for fees of non-market transferred properties (e.g. inheritance, gift, etc.) [24].

\section{Complementary Non-Agriculture Sector Policies}

The GoR also adopted several more broad policies to create economy-wide enabling environment, particularly to attract private sector and foreign direct investments for enhancing productivity expansion in agriculture. These reforms reflect government commitment through substantial investments in human capital (expenditure on health, education, for instance, growing by about $14 \%$ to $18 \%$, to reach a share of more than $4.6 \%$ of GDP by 2014) (Table 1); physical infrastructure (similar growth in hare of construction) and economic incentive schemes. These reforms played a key role in facilitating the transfer of labour and other key resources out of agriculture to other sectors, supporting transformation of the Rwandan economy from a highly agrarian to more service-based economy (Table 1). Table 1 clearly shows that the declining shares of agriculture in VAD and employment have been primarily absorbed by services' sectors (financial, trade and tourism) [25,26].

Table 1: Selected statistics for Rwanda (Percentages).

\begin{tabular}{|c|c|c|c|c|c|c|c|}
\hline & & & 1971-94 & 1995-2000 & 2001-2006 & 2007-2014 & $\begin{array}{c}\text { Growth Rates } \\
(\%)\end{array}$ \\
\hline & & & & & & 1996-2007 & 2008-2014 \\
\hline Shares of value added (\%) & & & & & GDP & 8.9 & 11.3 \\
\hline Agriculture, hunting, forestry; fishing & 56.5 & 43.8 & 40.7 & 35.4 & & 6 & 10.4 \\
\hline Manufacturing & 8.3 & 8.3 & 6.4 & 5.5 & & 3.6 & 11.5 \\
\hline Construction & 3.7 & 4.2 & 4.9 & 6.6 & & 9.9 & 17.8 \\
\hline $\begin{array}{l}\text { Wholesale, retail trade, hotels \& } \\
\text { restaurants }\end{array}$ & 12.19 & 12 & 13.2 & 16.1 & & 8.9 & 12.2 \\
\hline $\begin{array}{l}\text { Transport, storage and } \\
\text { communications }\end{array}$ & 1.9 & 2.8 & 4.5 & 5.6 & & 10.7 & 13.7 \\
\hline $\begin{array}{c}\text { Financial intermediation, real estate, } \\
\text { renting }\end{array}$ & 8.6 & 17.9 & 16.8 & 16.4 & & 6.8 & 9.7 \\
\hline
\end{tabular}




\section{Agricultural Research \& Technology: Open Access Journal}

\begin{tabular}{|c|c|c|c|c|c|c|c|}
\hline $\begin{array}{c}\text { Education; health, social work; other } \\
\text { community }\end{array}$ & 2 & 2.7 & 3.6 & 4.6 & 14 & 4.8 \\
\hline $\begin{array}{c}\text { Public administration, defence, social } \\
\text { security }\end{array}$ & 3.7 & 4.9 & 4 & 3.2 & & 27.7 \\
\hline $\begin{array}{c}\text { Private households with employed } \\
\text { persons }\end{array}$ & 1.1 & 1.7 & 4.5 & 4.3 & & 8.3 \\
\hline Mining and quarrying & 0.5 & 0.1 & 0.7 & 1.6 & & 45.2 & 21.3 \\
\hline Electricity, gas and water supply & 2.1 & 1.6 & 0.8 & 0.8 & & 6.6 & 3.8 \\
\hline Share in total employment (\%) & 2000 & 2006 & & & & & \\
\hline Agriculture & 89.5 & 79.5 & & & & \\
\hline Manufacturing & 1.7 & 3.3 & & & & \\
\hline Services & 8.7 & 17.2 & & & \\
\hline
\end{tabular}

\section{References}

1. IFAD (International Fund for Agricultural Development). (2016). Rural Development Report 2016, Fostering Inclusive Rural Transformation, IFAD, Rome, Italy.

2. AGRA (2016) Africa Agriculture Status Report: Progress towards agricultural transformation in Africa. Alliance for a Green Revolution in Africa, South Africa.

3. FAO (2017) The State of Food and Agriculture. Food and Agriculture Organization, Rome, Italy.

4. Lipton M (2009) Land reform in developing countries: Property rights and property wrongs. Routledge, London \& New York, USA.

5. Deininger K, Ali D, Alemu T(2011) Impacts of land certification on tenure security, investment, and land market participation. Evidence from Ethiopia. Land Economics 87(2): 312-334.

6. Alden Wily I (2011) The tragedy of public lands: The fate of the commons under global commercial pressure. An ILC Collaborative Research Project on Commercial Pressures on Land, ILC, Rome, Italy.

7. Lawry S, Samii C, Hall R, Leopold A, Hornby D, et al. (2014) The impact of land property rights interventions on investment and agricultural productivity in developing countries: A systematic review. Campbell Systematic Reviews 2014: 1.

8. CDP Committee for Development Policy (2017) Expanding Productive Capacity: Lessons Learned from Graduating Least Developed Countries, CDP Policy Note, Department of Economic and Social Affairs (DESA), United Nations, New York, USA.

9. Republic of Rwanda (2014) Promoting agricultural growth in Rwanda: Recent performance, challenges and opportunities, Rwanda Agricultural Policy Note, Republic of Rwanda, Kigali, Africa.

10. Republic of Rwanda (2004) National land policy, Ministry of Lands, Environment, Forests, Water, and Mines. Kigali, Africa.

11. NISR (2013) The Evolution of poverty in Rwanda from 200 to 2011: results from the Household Surveys (EICV). National Institute of Statistics of Rwanda, NISR, Kigali, Africa.

12. Republic of Rwanda (2009b) Economic development and poverty reduction strategy 2008-2013. Republic of Rwanda, Kigali, Africa.

13. Republic of Rwanda (2013b) Rwanda Vision 2010, Government of Rwanda, Kigali, Africa.

14. Republic of Rwanda (2009a) Strategic plan for the transformation of agriculture in Rwanda: Phase II, Final Report, Ministry of Agriculture and Animal Resources, Kigali, Africa.
15. Republic of Rwanda (2013a) Law N ${ }^{\circ} 43 / 2013$ Governing Land in Rwanda, Official Gazette, Kigali, Africa.

16. WB (2011) Seeds for higher growth, Rwanda Economic Update. World Bank, Washington, USA.

17. Kathiresan A (2012) Farm land use consolidation in Rwanda: Assessment from the perspective of agriculture sector, Ministry of Agriculture and Animal Resources, Republic of Rwanda, Kigali, East Africa.

18. Musahara H, Nyamulinda B, Bizimana C, Niyonzima T (2014) Land use consolidation and poverty reduction in Rwanda, Presented at the World Bank Conference on Land and Poverty. The World Bank, Washington, USA.

19. Andre C, Plateau P (1998) Land relations under unbearable stress: Rwanda caught in the Malthusian trap. Journal of Economic Behavior and Organization 34(1): 1-47.

20. Global IDP project (2005) Ensuring durable solutions for Rwanda's displaced people: a chapter closed to early.

21. Boudreaux K (2009) Land Conflict and Genocide in Rwanda. The Electronic Journal of Sustainable Development 1(3): 85-95.

22. Ayalew AD, Deininger K, Duponchel M, Ronchi L (2012) Case Study: How Land Tenure Regularization can contribute to agricultural growth in Rwanda. Development Researcg Group, World Bank, Washington, USA.

23. Sagashya D (2014) Land Tenure Reform in Developing Countries: What can we learn from Rwanda? Presentation in the World Bank Land and Poverty Conference, Washington, USA.

24. Biraro M, Khan S, Konguka G, Ngabo V, Kanyiginya V, et al. (2015) Final Report of Study on the access to the land tenure administration system in Rwanda and the outcomes of the system on ordinary citizens. USAID, LAND Project, Kigali, East Africa.

25. Ali D, Deininger K, Goldstein M (2014) Environmental and gender impacts of land tenure regularization in Africa: Pilot evidence from Rwanda. Environment and Development Economics 110: 262-275.

26. Musahara H, Huggins C (2005) Land reform, land scarcity and postconflict reconstruction: A case study of Rwanda. In: Huggins C, Clover J (Eds.), From the Ground up: Land rights, conflict and peace in SubSaharan Africa. Institute of Security Studies, Pretoria and Cape Town.

27. UNSD (2016). National Accounts Main Aggregates Database, downloaded from UNCTAD Stat. United Nation Statistics Division, USA. 


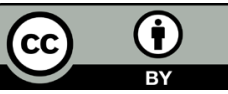

This work is licensed under Creative Commons Attribution 4.0 License

DOI: 10.19080/ARTOAJ.2018.14.555934
Your next submission with Juniper Publishers will reach you the below assets

- Quality Editorial service

- Swift Peer Review

- Reprints availability

- E-prints Service

- Manuscript Podcast for convenient understanding

- Global attainment for your research

- Manuscript accessibility in different formats ( Pdf, E-pub, Full Text, Audio)

- Unceasing customer service

Track the below URL for one-step submission https://juniperpublishers.com/online-submission.php 